\title{
Colon Perforation in a 22-year-old Male with Bartter's Syndrome, Systemic Lupus Erythematosus and Leishmaniasis
}

\author{
Francesk Mulita', Michail Vailas', Maria Sotiropoulou², Nikoleta Oikonomou ${ }^{3}$, Sotirios Koureleas ${ }^{1}$, Ioannis Maroulis
}

'Department of General Surgery, General University Hospital of Patras, Achaia, Greece

2Department of Surgery, Evangelismos General Hospital, Greece

${ }^{3}$ Department of Pediatrics, Neonatal Intensive Care Unit, General University Hospital of Patras, Achaia, Greece

${ }^{*}$ Corresponding author:

Francesk Mulita MD, MSc, PhD(c)

Resident Surgeon at the Department of Surgery, General University Hospital of Patras, Achaia, Greece E-mail: oknarfmulita@hotmail.com ORCID Id: https://orcid.org/0000-0001$7198-2628$

\section{Rezumat}

Perforatie colonică în cazul unui pacient de 22 de ani diagnosticat cu sindrom Bartter, lupus eritematos systemic și leishmanioză

Sindromul Bartter (SB) este o afecțiune genetică tubulară renală, caracterizată prin hipocloremie, hipokaliemie şi alcaloză metabolică. Prognosticul sindromului Bartter depinde de severitatea disfuncției de receptor. In majoritatea cazurilor, prognosticul este favorabil, iar pacientii pot avea o viață relativ normală. Lupusul eritematos sistemic (LES) este o boală cronică autoimună de cauză necunoscută care, teoretic, poate afecta orice organ. Prognosticul LES este variabil, în funcție de gravitatea bolii, de evoluția clinică şi de organele implicate. În ultimele decenii, se constată o îmbunătătire semnificativă a supraviețuirii pacienților datorită diagnosticului şi tratamentului precoce. În ciuda acestor îmbunătățiri, pacienții cu LES au încă o rată de mortalitate ridicată, de două până la cinci ori mai mare decât cea a populației generale. Leishmanioza este o boală cauzată de un parazit protozoar intracelular transmis de muşcătura femelei țânțarului flebotom. Acest articol prezintă cazul unui tânăr de 22 de ani cunoscut cu SB şi LES care a fost internat în clinica de medicină internă pentru leishmanioză. În a treia zi de spitalizare, s-a practicat operația Hartmann pentru apariția unei perforații localizate pe colonul descendent. Gestionarea pacienților cu multiple comorbidități severe reprezintă o provocare pentru profesioniştii din domeniul medical.

Cuvinte cheie: Sindrom Bartter, Lupus eritematos, Leishmanioză, perforarea colonului 


\section{Abstract}

Bartter's syndrome (BS) is an inherited renal tubular disorder characterized by hypochloremia, hypokalemia, metabolic alkalosis. Prognosis of Bartter's syndrome depends on the severity of the receptor dysfunction. In many cases the prognosis is good and patients are able to have fairly normal lives. Systemic lupus erythematosus (SLE) is a chronic autoimmune disease of unknown cause that can affect virtually any organ of the body. The prognosis of SLE is quite variable, depending on the severity of the disease, the clinical course and organs involved. The last decades, there is a marked improvement in patient survival due to earlier diagnosis and treatment. Despite these improvements, patients with SLE still have higher mortality rates ranging from two to five times higher than that of the general population. Leishmaniasis is a disease caused by an intracellular protozoan parasite transmitted by the bite of a female phlebotomine sandfly. We report herein the case of a 22-year-old man with Bartter's syndrome (BS) and Systemic lupus erythematosus (SLE), who was hospitalized in the clinic of internal medicine because of Leishmaniasis. In the third day of his hospitalization the patient underwent Hartmann's operation for perforation located on descending colon. Management of patients with many severe diseases is very difficult for medical professionals.

Key words: Bartter syndrome, lupus erythematosus, leishmaniasis, colon perforation

\section{Introduction}

Bartter's syndrome (BS) is an inherited renal tubular disorder characterized by hypokalemia, hypochloremic metabolic alkalosis, and hyperaldosteronism, while blood pressure is normal (1). Systemic lupus erythematosus (SLE) is a multisystem disease with several phenotypes and unknown exact etiology (2). This study aimed to present a young man with BS, SLE as well as Leishmaniasis who underwent Hartmann's operation for perforation located on descending colon.

\section{Case Report}

A 22-year-old man with Bartter's syndrome (BS) and Systemic lupus erythematosus (SLE) was hospitalized in the clinic of internal medicine because of Leishmaniasis. During his hospitalization the patient was taking $32 \mathrm{mg}$ of methylprednisolone per day as well as $90 \mathrm{mg}$ of indomethacin. In the third day of his hospitalization, patient complained of abdominal pain, which was maximal in the left side. On examination, the patient's temperature was 37.7 , heart rate was 115 beats per minute, blood pressure was 95/71 and respiratory rate was 22 breaths per minute. His abdomen was hard, with distension and tenderness. The initial haemoglobin was $7 \mathrm{~g} / \mathrm{dL}$, white blood cells were $0.85 \mathrm{~K} / \mathrm{\mu l}$ and C-reactive protein level was $15.3 \mathrm{U} / \mathrm{l}$. Biochemical tests revealed hypokalemic hypochloremic metabolic alkalosis (serum potassium $2.7 \mathrm{mEq} / \mathrm{L}$; chloride $85 \mathrm{mEq} / \mathrm{L}$; bicarbonate $32 \mathrm{mEq} / \mathrm{L} ; \mathrm{pH}$ 7.52; and PCO2 39 $\mathrm{mm})$. Liver and renal function test, serum amylase and lipase were normal. A computed tomography (CT) scan of the abdomen was performed immediately and pneumoperitoneum was well recognized (Fig. 1).

The patient underwent Hartmann's procedure and two small holes were found on descending colon. The patient appeared well when the surgery was performed. After resection of the perforation area, colostomy was performed. Now the patients is 25 years old and the serum electrolytes and creatinine clearance are within the normal range.

\section{Discussion}

Bartter syndrome is a autosomal recessive 


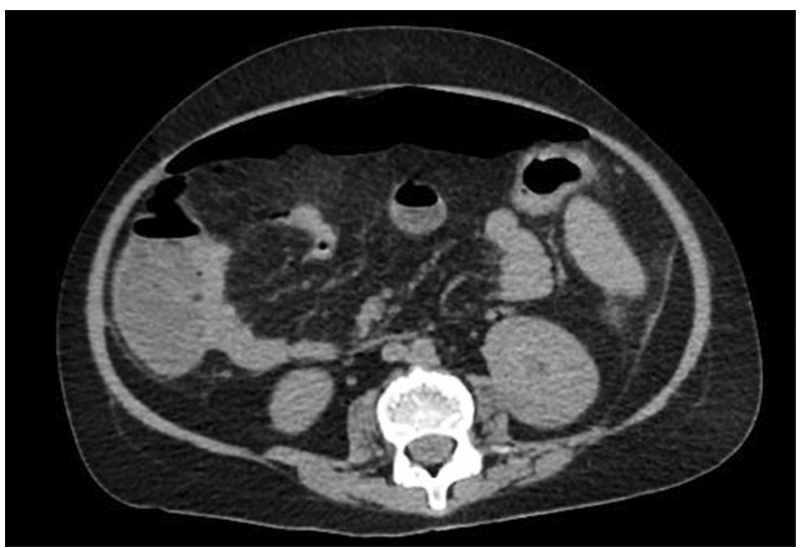

Figure 1. 22 year old male with abdominal pain. CT abdomen reveals colon perforation

disorder with an estimated prevalence 1 case in 1,000,000 population (3). The primary defect in Bartter syndrome is an impairment in one of the transporters involved in sodium chloride reabsorption in the loop of Henle (4). There have been described five types of Barter syndrome. These are caused by mutations in different genes. Type I results from mutations in the sodium chloride/potassium chloride cotransporter gene. Type II results from mutations in the ROMK gene. Classic Bartter syndrome (type III) results from mutations in the chloride-channel gene. Neonatal Bartter syndrome (type IV) is associated with sensorineural deafness and results from mutations in the BSND gene. Type IVb Bartter syndrome is associated with sensorineural deafness but is not caused by mutations in the BSND gene. Type $\mathrm{V}$ Bartter syndrome results from mutations in the genes that encode the chloride channel subunits $\mathrm{ClC}-\mathrm{Ka}$ and $\mathrm{ClC}-\mathrm{Kb}(5,6)$. This impairment in sodium reabsorption leads to distinct metabolic abnormalities. Specifically, impaired sodium chloride reabsorption leads to volume depletion and secondary activation of the renin-angiotensin-aldosterone system. High levels of aldosterone cause sodium aborption and potassium excretion into the lumen by principal cells. High levels of angiotensin lead to a secondarily rise in vaso dilating prostaglandin E (PGE) levels. Furthermore, excessive distal sodium delivery increases distal tubular sodium reabsorption and exchange potassium and hydrogen ion, which leads to hypokalemia and metabolic alkalosis. Impairement of chloride reabsorption promotes inadequate exchange of bicarbonate for chloride, which leads to hypochloremia and metabolic alkalosis. Patients with Bartter syndrome often have hypercalciuria, due to impairment of chrolide reabsorption. Normally, reabsorption of the negative chloride ions promotes a lumen-positive voltage, driving paracellular positive calcium and magnesium absorption. The neonatal type of Bartter syndrome is characterized by maternal polyhydramnios in 24-30 weeks of gestation due to fetal polyuria and by life-threatening episodes of fluid loss in the neonatal period. The classic type of Bartter syndrome is characterized by metabolic abnormalities (hypochloremia, hypokalemia, metabolic alkalosis), failure to thrive, due to high levels of prostaglandin $\mathrm{E}$, polyuria, polydipsia due to decreased urinary concentrating ability, low blood pressure due to volume depletion, muscle weakness and recurrent carpopedal spasms, due to low levels of calcium in the blood. There have been described life-threatening complications in Bartter syndrome such as cardiac arrhythmias and cardiac sudden death, resulting from electrolyte disturbances. There have been used several types of treatment of Bartter syndrome including: Sodium, potassium, calcium and magnesium supplements, angiotensin-converting enzyme inhibitors, aldosterone antagonists and diuretic spironolactone, indomethacin or ibuprofen (used to decrease prostaglandin excretion). Prognosis of Bartter syndrome depends on the severity of the receptor dysfunction. In many cases the prognosis is good and patients are able to have fairly normal lives (7-9).

Systemic lupus erythematosus (SLE) is a chronic autoimmune disease of unknown cause that can affect virtually any organ of the body. Multiple factors are associated with the development of the disease, including genetic, epigenetic, immunoregulatory and environmental factors (10). The prevalence of systemic lupus erythematosus (SLE) in the United States is 20 to 150 cases per 100,000. 
Mostly women are affected. Constitutional symptoms such as fatigue, weight loss, fever, myalgia are quite common in patients affected by SLE. Arthritis and arthralgias occur in over 90 percent of patients with SLE and are often one of the earliest manifestations. The most common affected joints are the proximal interphalangeal (PIP), the metacarpophalangeal (MCP) joints of the hands, and the wrists. Most patients develop skin and mucous membrane lesions. The most common skin lesion is called "butterfly rash", which is a facial eruption that spares the nasolabial folds. Other cutaneous findings are discoid rash, photosensitive rash (which is often macular or diffusely erythematous in sunexposed areas of the face, arms and hands) and alopecia. Renal involvement is a significant cause of morbidity and mortality in patients with lupus. It is manifested by hypertension, hematuria, proteinuria (nephrotic syndrome) (11). Thromboembolic disease can complicate SLE. Cardiac manifestations include Libman-Sacks endocarditis and pericarditis, hematologic manifestations include leukopenia, thrombocytopenia and hemolytic anemia. Funduscopic examinationis of outmost importance in patients with SLE as retinal vasculitis can lead to blindness. The presence of antinuclear antibodies (ANA), anti-double-stranded DNA (anti-dsDNA), antiphospholipid antibodies, low $\mathrm{C} 3$ and $\mathrm{C} 4$ levels, high erythrocyte sedimentation rate (ESR) and/or C-reactive protein (CRP) support the diagnosis of SLE. Due to the clinical heterogeneity of SLE, the therapeutic approaches are highly variable, depending on the predominant organ involved. Hydroxychloroquine and chloroquine are the most common medication used in patients with SLE. Patients with severe or life-threatening manifestations secondary to major organ involvement (eg, renal) require high doses of systemic glucocorticoids for a short period of time. Other medications that are commonly used are immunosuppressive agents such as mycophenolate, azathioprine, and cyclophosphamide, and human monoclonal antibodies such as or Rituximab and Belimumab. The prognosis of SLE is quite variable, depending on the severity of the disease, the clinical course and organs involved. The last decades, there is a marked improvement in patient survival due to earlier diagnosis and treatment. Despite these improvements, patients with SLE still have higher mortality rates ranging from two to five times higher than that of the general population. The major causes of death in the first few years of illness are active disease with CNS and/or renal involvement or infection due to immunosuppression (12-13).

Leishmaniasis is a disease caused by an intracellular protozoan parasite transmitted by the bite of a female phlebotomine sandfly. Leishmaniasis is categorized in 3 major types: cutaneous-localised and disseminated, mucocutaneous and visceral-kala azar. Cutaneous leishmaniasis is the most common type. Localized cutaneous leishmaniasis begins as a papule that enlarges and develops into a nodule or plaque-like lesion leading to a painless ulceration. Disseminated cutaneous leishmaniasis manifestations include multiple, widespread nontender, nonulcerating cutaneous papules and nodules. Mucocutaneous leishmaniasis manifestations include erosion, and ulceration of the palate, uvula, lips, pharynx, and larynx and gingivitis. Visceral leishmaniasis is the most severe form of leishmaniasis. Visceral leishmaniasis manifestations include fever, weight loss, hepatosplenomegaly, pancytopenia, and hypergammaglobulinemia. Due to severe thrombocytopenia epistaxis and petechiae may occur. Anemia is normochromic and normocytic and caused by several factors, including replacement of marrow by the parasites, splenic sequestration, hemorrhage, and hemolysis. Leukopenia may also be observed and may contribute to secondary infections.

In 2015, World Health Organization reported about 200,000 incident cases of visceral leishmaniasis. The annual incidence of cutaneous leishmaniasis is estimated to be 0.7 to 1.2 million new cases per year. Laboratory diagnosis of leishmaniasis can be made by isolation, visualization, and culturing of the 
parasite from infected tissue, serologic detection of antibodies to recombinant K39 antigen and polymerase chain reaction (PCR). Definive diagnosis is made by the demonstration of parasite by smear or culture in tissue, usually bone marrow or spleen. Treatment options are based on the type of leishmaniasis and the severity of the disease. Many cutaneous lesions eventually resolve without treatment. For certain types of cutaneous leishmaniasis where the potential for mucosal spread is low, topical paromomycin can be used. For more invasive lesions (eg, those failing to respond to topical treatment; metastatic spread to the lymph nodes; or large, and multiple skin lesions, especially those on the face, near mucosal surfaces, or near joints), sodium stibogluconate or pentamidine can be used. Mucocutaneous disease responds to a 20-day course of sodium antimony gluconate. Amphotericin B may also be used to treat advanced or resistant cases (14-15).

There is a case report in the literature which showed a colon perforation in a newborn diagnosed with antenatal BS after taking indomethacin for 3 days in the $8^{\text {th }}$ day of life. In addition, the mother was treated with indomethacin from 26 to 31 week of gestation. Administration of indomethacin in both prenatal and early postnatal period has been implicated as a significant risk factor for colon perforation (1). In our case, the patient was 22 years old and he was also taking methylprednisolone, because of SLE. That can also be responsible for perforation of the colon.

Evaluation of a patient with suspected bowel perforation must focus on a thorough history (regular medication use of Nonsteroidal anti-inflammatory drugs (NSAIDs), corticosteroids and chemotherapy) and physical exam. According to the literature, there is an association between corticosteroids use and colon perforation (16). In addition, corticosteroids, such as methylprednisolone is associated with clearly increased mortality risk after perforated diverticular disease. Thus, use of corticosteroids should be regarded as an important clinical prognostic factor for mortality in patients with this condition (17). In our patient, colon perfo- ration was presented as the 22-year-old male was taking methylprednisolone beacause of SLE and indomethacin because of Bartter's Syndrome. Fortunately, the patient was operated immediately after perforation was diagnosed. A $12^{-} \mathrm{cm}$ midline insicion was performed, because of the small body of our patient. Fecal pertitonitis was recognized, as well as two small holes were found on descending colon. Hartmann's procedure was performed and a drain was placed in pouch of Douglas. He was mobilized 24 hours postoperatively and started on oral diet on postoperative day four. During his hospitalization surgical site infection was appeared on postoperative day six. This post-operative complication was managed empirically with meropenem, vancomycin and anidulafungin for 10 days. A multidrug-resistant Klebsiella Pneumoniae was detected from a wound culture performed and this bacterial pathogen was sensitive only to tygecycline. The patient remained in our clinic for 30 days after starting the treatment with tygecycline and was discharged home in a very good condition.

\section{Conclusions}

The management of patient with many severe diseases is very difficult for medical professionals. The fact that these patients take many different drugs for each disease makes it very difficult to find the cause of any complications, such as colon perforation. In addition, the management of our patient was very difficult because he was taking corticosteroids after the procedure, which is a risk factor for surgical site infection. Many healthcare professionals, such as infectious disease specialists, rheumatologists and surgeons worked together and examine the patient every day in order to have this good result.

\section{Conflicts of Interest}

The authors certify that there is no conflict of interest with any financial organization regarding the material discussed in the manuscript. 


\section{Funding}

The authors report no involvement in the research by the sponsor that could have influenced the outcome of this work.

\section{Authors' Contributions}

All authors contributed equally to the manuscript and read and approved the final version of the manuscript.

\section{References}

1. Ataoglu E, Civilibal M, Ozkul AA, Varal IG, Oktay ER, Murat E Indomethacin-induced colon perforation in Bartter's syndrome. Indian J Pediatr. 2009;76(3):322-323

2. Justiz Vaillant AA, Goyal A, Bansal P, Varacallo M. Systemic Lupus Erythematosus (SLE) [Updated 2020 Apr 7]. In: StatPearls [Internet] Treasure Island (FL): StatPearls Publishing;2020 Jan. Available from: https://www.ncbi.nlm.nih.gov/books/NBK535405/

3. Blanchard A, Bockenhauer D, Bolignano D, Calò LA, Cosyns E, Devuyst 0 , et al. Gitelman syndrome: consensus and guidance from a Kidney Disease: Improving Global Outcomes (KDIGO) Controversies Conference. Kidney international. 2017:91(1):24-33.

4. Konrad M, Weber S. Recent advances in molecular genetics of hereditary magnesium-losing disorders. J Am Soc Nephrol. 2003:14(1):249-60.

5. Fremont OT, Chan JC. Understanding Bartter syndrome and Gitelman syndrome. World J Pediatr. 2012;8(1):25-30.
6. Krämer BK, Bergler T, Stoelcker B, Waldegger S. Mechanisms of Disease: the kidney-specific chloride channels CICKA and CICKB, the Barttin subunit, and their clinical relevance. Nat Clin Pract Nephrol. 2008;4(1): $38-46$.

7. Blanchard A, Vargas-Poussou R, Vallet M, Caumont-Prim A, Allard J, Desport E, et al. Indomethacin, amiloride, or eplerenone for treating hypokalemia in Gitelman syndrome. J Am Soc Nephrol. 2015;26(2):468-75.

8. Gasongo G, Greenbaum LA, Niel 0, Kwon T, Macher MA, Maisin A, et al. Effect of nonsteroidal anti-inflammatory drugs in children with Bartter syndrome. Pediatr Nephrol. 2019;34(4):679-684.

9. Nascimento CL, Garcia CL, Schvartsman BG, Vaisbich MH. Treatment of Bartter syndrome. Unsolved issue. J Pediatr (Rio J). 2014;90(5):512-7.

10. Rahman A, Isenberg DA. Systemic lupus erythematosus. N Engl J Med. 2008:358(9):929-39.

11. Danila MI, Pons-Estel GJ, Zhang J, Vilá LM, Reveille JD, Alarcón GS. Renal damage is the most important predictor of mortality within the damage index: data from LUMINA LXIV, a multiethnic US cohort. Rheumatology (0xford). 2009;48(5):542-5.

12. Ward MM, Pyun E, Studenski S. Mortality risks associated with specific clinical manifestations of systemic lupus erythematosus. Arch Intern Med. 1996;156(12):1337-44.

13. Singh RR, Yen EY. SLE mortality remains disproportionately high, despite improvements over the last decade. Lupus. 2018;27(10):1577-1581.

14. Tiuman TS, Santos A0, Ueda-Nakamura T, Filho BP, Nakamura CV. Recent advances in leishmaniasis treatment. Int J Infect Dis. 2011;15(8):e525-32.

15. Singh OP, Singh B, Chakravarty J, Sundar S. Current challenges in treatment options for visceral leishmaniasis in India: a public health perspective. Infect Dis Poverty. 2016;5(1):19.

16. Sterioff S, Orringer MB, Cameron JL. Colon perforations associated with steroid therapy. Surgery. 1974;75(1):56-58

17. Broersen L, Horváth-Puhó E, Pereira AM, Erichsen R, Dekkers OM, Sørensen HT. Corticosteroid use and mortality risk in patients with perforated colonic diverticular disease: a population-based cohort study. BMJ Open Gastroenterol. 2017:4(1):e000136. 